\title{
ЗНАЧЕНИЕ КОММУНИКАТИВНОЙ МОБИЛЬНОСТИ В ПРОФЕССИОНАЛЬНОЙ ДЕЯТЕЛЬНОСТИ МУЗЬКОВЕДА
}

\section{THE IMPORTANCE OF COMMUNICATIVE MOBILITY IN THE PROFESSIONAL ACTIVITY OF A MUSICOLOGIST}

N. Kucher

Summary: The article considers the importance of communicative mobility as an important professional quality in the activity of a musicologist. The current definitions of this concept are given, including in relation to the activities of a musicologist. The article deals with the main features of the professional activity of a musicologist, which includes three basic directions-pedagogical, scientific, and educational. Within these areas, the following parameters of audience division are justified: age, profession, and level of education. In accordance with these parameters, the main features of various types of audiences with which the musicologist interacts in his professional activity are considered. The article also discusses the specifics of the communicative activity of a musicologist in connection with interaction with musical works. The musicologist is considered as an organic part of the musical-communicative chain "composer-performer-musicologist-listener".

Keywords: communicative mobility, musicologist, features of professional activity of a musicologist.

\author{
Кучер Наталья Юрьевна \\ К.п.н., Южно-Уральский государственный институт \\ искусств им. П.И. Чайковского (г. Челябинск) \\ nataljakucher@yandex.ru
}

Аннотация: В статье рассматривается значение коммуникативной мобильности как важного профессионального качества в деятельности музыковеда. Даются существующие на сегодняшний день определения данного понятия, в том числе применительно к деятельности музыковеда. Рассматриваются основные особенности профессиональной деятельности музыковеда, которая включает в себя три базовых направления - педагогическое, научное, просветительское. В рамках данных направлений обосновываются следующие параметры деления аудитории: возраст, профессия, уровень образования. В соответствии с указанными параметрами рассматриваются основные особенности различных типов аудиторий, с которыми взаимодействует музыковед в своей профессиональной деятельности. Также в статье рассматривается специфика коммуникативной деятельности музыковеда в связи с взаимодействием с музыкальными произведениями. Музыковед рассматривается как органичная часть музыкально-коммуникативной цепи «композитор-исполнитель-музыковед-слушатель».

Ключевые слова: коммуникативная мобильность, музыковед, особенности профессиональной деятельности музыковеда.

состояние наивысшей готовности к взаимодействию с различными участниками образовательных отношений в школе» [1, с. 40].

О.В. Смирнова, изучая особенности коммуникативной мобильности экономистов-международников, определяет ее как «способность специалиста осуществлять качественное общение в разнообразных, в том числе непредвиденных ситуациях» $[2$, с. 9].

По мнению О.А. Романовой - исследователя, изучающего особенности коммуникативной мобильности сотрудников информационных подразделений МЧС России, коммуникативная мобильность - это «способность сотрудника осуществлять качественное общение в разнообразных, в том числе, непредвиденных ситуациях, требующих проявления чувствительности и терпимости к фактору коммуникативной неопределенности <...> в сложных условиях межкультурного общения» [3].

Таким образом, коммуникативная мобильность специалистов разных сфер позволяет, прежде всего, осуществлять качественное вербальное взаимодействие в различных, в том числе непредвиденных ситуациях 
профессиональной деятельности.

Применительно к деятельности музыковеда коммуникативная мобильность определяется нами как «профессионально важное качество, обеспечивающее гибкое изменение стиля общения, модели поведения и средств коммуникации (в том числе невербальной) в соответствии с музыкально-социальной ролью, художественно-эстетическими потребностями и особенностями музыкального восприятия реципиентов разных возрастных категорий и социально-профессиональных групп» $[4$, с. 7].

Поясним наше определение, опираясь на особенности профессиональной деятельности музыковеда.

Профессия музыковеда среди других музыкальных специальностей является одной из самых многоплановых. Это объясняется тем, что музыковед совмещает сразу несколько направлений в профессиональной деятельности. Наиболее обобщенно можно выделить три базовых - педагогическое, научное и просветительское. Остановимся подробнее на каждом из них.

В рамках педагогического направления музыковед ведет педагогическую деятельность в различных образовательных организациях. Это учреждения дополнительного образования детей и взрослых, учреждения общего образования, учреждения специального музыкального образования, в том числе профессионального уровня. В каждом из таких образовательных учреждений присутствует своя специфика педагогической работы.

Суть научного направления работы музыковеда проведение различного рода научных исследований. Работа может вестись как над отдельными музыкальными произведениями, над творчеством композиторов в целом, так и над осмыслением более крупных пластов музыкального искусства. Также к научному направлению можно отнести редактирование различных нотных изданий или изданий, посвященных проблемам музыкального искусства; создание книг о музыке и музыкантах; написание рецензий и критических заметок о событиях музыкальной жизни и т.д.

И, наконец, третье направление профессиональной деятельности музыковеда - просветительское. Оно включает в себя проведение концертов, лекций, бесед о музыке, теле- и радиопередач, а также выступления в средствах массовой информации и многое другое.

Опираясь на вышесказанное, можно сделать вывод о том, что профессия музыковеда основана, прежде всего, на коммуникации, преимущественно вербальной, в процессе которой могут возникать различные, в том числе непредвиденные ситуации профессиональной деятельности.
В этой связи необходимо пояснить следующее. Вся профессиональная деятельность музыковеда, будь то педагогическая, научная или просветительская, направлена на коммуникативное взаимодействие с различными типами аудиторий. В научной литературе дается как достаточно общее определение понятия «аудитория»«объект информационного воздействия» [5, с. 82], так и более подробное объяснение данного термина. Например, «Энциклопедический словарь СМИ» определяет аудиторию как «общее количество людей, являющихся читателями, слушателями, зрителями. Это публика, воспринимающая информацию в зависимости от своих социально-демографических и культурно-образовательных характеристик» [6, с. 18].

Указанные в данном определении основные критерии деления публики мы экстраполировали на музыковедческую деятельность, и в соответствии с особенностями данного вида деятельности определили основные параметры деления аудитории, с которой взаимодействует музыковед, а именно: возраст, профессия и уровень образования. В опоре на вышеуказанные параметры, в каждом из основных направлений деятельности музыковеда можно выделить разные типы аудитории.

Так, по возрастному критерию, для педагогического направления целесообразным будет выделение таких возрастных периодов как: дошкольное детство; младший школьный возраст; подростковый возраст; юность. В современных условиях в рамках педагогического направления можно также говорить о взаимодействии музыковеда с аудиторией зрелого возраста, учитывая стремление взрослых людей к обучению музыке и наличие музыкальных школ и других образовательных учреждений для взрослых.

В рамках просветительского направления возрастные типы аудитории значительно расширяются, поскольку работа музыковеда-просветителя направлена как на детей дошкольного и школьного возраста, так и на юношескую аудиторию (студенты), а также зрелых и пожилых людей - то есть, по сути, охватывает практически все возрастные периоды жизни человека.

Исследуя особенности научного направления, мы выяснили, что этот вид профессиональной деятельности музыковеда может быть обращен к аудитории всех возрастов, за исключением дошкольного и младшего школьного возраста.

Таким образом, с точки зрения возрастного критерия музыковед в своей профессиональной деятельности взаимодействует с аудиторией всех возрастов.

Рассматривая потенциальную аудиторию музыковеда с точки зрения профессиональной принадлежно- 
сти и уровня образования, мы выделили три основные группы реципиентов. Это музыканты-профессионалы, музыканты любители и музыкально несведущая аудитория. Разделение аудитории по данным признакам позволяет определить особенности восприятия музыкального искусства профессиональными музыкантами и любителями. Как отмечает Д.К. Кирнарская, «музыкальное восприятие музыкантов-профессионалов и элитной части слушательской аудитории отличается повышенной аналитичностью, абстрактностью, способностью к органическому сочетанию дифференцированности и иерархичности» [7, с. 89]. Исследователь также считает, что для восприятия рядового слушателя характерны точечность, фрагментарность, конкретность и внимание к единичному явлению как таковому [там же]. Сходной позиции придерживается и Л.Л. Бочкарев, отмечая, что «чем выше уровень подготовленности слушателя до знакомства с музыкальным произведением, тем оно доступнее для него» [8, с. 123].

Необходимо отметить, что для различных типов аудитории, разделяемых по возрастному и профессиональному признакам, помимо различий в музыкальном восприятии характерна и существенная разница в художественно-эстетических потребностях. Исследователи считают, что художественные потребности, как одни из высших форм духовных потребностей человека, способствуют формированию внутреннего мира человека через искусство [9, с. 27]. Мы понимаем художественноэстетические потребности как «потребности личности в восприятии художественных и эстетических объектов, обусловленные общим уровнем художественного и эстетического развития субъекта и выражающиеся в необходимости взаимодействия с художественной культурой и произведениями искусства, а также самостоятельного участия в создании художественных ценностей» $[10$, c. 50].

Таким образом, специфика коммуникативного взаимодействия музыковеда с различными типами аудиторий в педагогической, просветительской и научной деятельности определяется как возрастными особенностями, так и особенностями восприятия, художественноэстетическими потребностями, которые, в свою очередь, определяются характером профессиональной деятельности и уровнем образования респондентов.

Однако, процесс общения музыковеда с аудиторией связан не только с взаимодействием с различными типами аудиторий. Спецификой коммуникативной деятельности музыковеда, тем, что отличает ее от других видов коммуникации, является взаимодействие с музыкальными произведениями. Иначе говоря, музыковед, наряду с исполнителем, выступает своеобразным посредником между композитором, создавшим музыкальное произведение, и его «потребителем» - учеником, слушателем (зрителем), читателем. Музыковед в каждом виде своей профессиональной деятельности познает и истолковывает смысл музыкального произведения, а затем доносит его до адресата. В связи с этим, становится очевидным, что в основе любого вида музыковедческой деятельности лежит процесс музыкальной коммуникации.

Ученые, исследующие проблемы музыкальной коммуникации (Б.В. Асафьев, Л.Л. Бочкарев, В.В. Медушевский, Е.В. Назайкинский и др.) сходятся во мнении, что музыкальное искусство очень информативно по своей сути. Через музыкальные произведения постигаются традиции и опыт прошлых эпох и современности, люди приобщаются к общечеловеческим ценностям и обогащают собственный духовный мир. Композиторское творчество - это своеобразный процесс зашифровки, «перевода духовно-художественного содержания из идеальной (мысленно-чувственной) в материализованную форму» [11, с. 13].

В свою очередь, исполнители, а вместе с ними и слушатели, производят декодирование - то есть считывают информацию о композиторе, о системе его мировоззренческих ценностей, о ценностях эпохи, в которую он творил и т.д.

Б.В. Асафьев в своих трудах неоднократно подчеркивает, что существование музыкального искусства невозможно без сопряженности творчества, интонирования и восприятия. Данный исследователь впервые рассмотрел музыкально-коммуникативный процесс как триаду «композитор-исполнитель-слушатель». Эта мысль находит продолжение в трудах Л.Л. Бочкарева, В.В. Медушевского и др.

Однако, существует и несколько иная точка зрения. В исследованиях таких ученых как И.А. Корсакова, Л.А. Птушко, Е.Р. Сизова, А.Н. Якупов и др., процесс музыкальной коммуникации дополняется четвертым звеном - музыковедом. Так, Л.А. Птушко определяет роль музыковеда как посредника между музыкой и обществом [12], А.Н. Якупов выделяет четыре уровня общения, обусловленного музыкальным произведением: «композиторский, исполнительский, слушательский и музыковедческий» $[11$, c. 15].

Мы придерживаемся сходной позиции и считаем, что музыковед является важным и необходимым связующим звеном в музыкально-коммуникативной цепи «композитор-иполнитель-музыковед-слушатель» и в любом виде своей профессиональной деятельности является посредником. Изучая музыкальные произведения, а также явления музыкального искусства в целом, с помощью слова, устного или письменного, музыковед раскрывает для аудитории сущность музыкальных произведений, и, шире, сущность музыкального искусства. Другими сло- 
вами, музыковед способствует декодированию смысла, заложенного в музыкальном тексте.

Необходимо подчеркнуть еще один важнейший аспект. Музыковед, выполняя каждый из основных видов своей профессиональной деятельности и способствуя декодированию зашифрованной информации в музыкальных произведениях, при каждом акте взаимодействия занимает разные позиции по отношению к партнерам по коммуникации. Это может быть позиция учителя, собеседника, наставника, критика, лектора, интервьюера и т.д. В соответствии с занимаемой позицией, музыковед каждый раз выполняет разные музыкально-социальные роли (музыковед-педагог, музыковедученый, музыковед-просветитель) и использует разные лексику, формы поведения, манеру общения, средства невербальной коммуникации. Например, при общении с профессиональными музыкантами музыковед использует сложную лексику с применением профессиональных терминов. Напротив, при коммуникативном взаимодействии с музыкально несведущей аудиторией необходимо избегать использования в речи сложного терминологического аппарата, а также важно преподносить материал в увлекательной форме для того, чтобы заинтересовать публику и привлечь внимание к явлениям музыкального искусства.

\section{Подведем итог.}

Исходя из особенностей профессиональной деятельности музыковеда, мы выделили три основных направления - педагогическое, просветительское и научное. В каждом из этих направлений музыковед взаимодействует с различными типами респондентов, подразделяемых нами по возрастному признаку, а также в зависимости от профессиональной принадлежности и уровня образования. Общение музыковеда с каждой из указанных возрастных и социально-профессиональных групп должно иметь существенные различия.

Для того, чтобы коммуникативное взаимодействие с аудиториями разных типов соответствовало уровню подготовленности респондентов, музыковеду необходимо учитывать особенности музыкального восприятия и художественно-эстетические потребности. В связи с этим, на первый план выходит проявление такого важного профессионального качества как коммуникативная мобильность, которая, по нашему мнению, и способствует обеспечению адекватного взаимодействия музыковеда с аудиторией с целью расшифровки и донесения смысла явлений музыкального искусства до реципиентов разных возрастных категорий и социально-профессиональных групп.

\section{ЛИТЕРАТУРА}

1. Алгаев А.Н. Развитие коммуникативной мобильности будущих педагогов-психологов в процессе профессиональной подготовки в вузе: дис. ... канд. псих. наук / Владикавказ, Северо-осетинский гос. ун-т им. К Хетагурова. 2013. 200 с.

2. Смирнова 0.В. Формирование коммуникативной мобильности студентов экономического вуза: автореф. дис. ... канд. пед. наук / Москва, Московский гос. пед. ун-т. 2013. 24 с.

3. Романова 0.А. Влияние корпоративной этики на коммуникативную мобильность сотрудников информационных подразделений МЧС / Интернет-журнал «Технологии техносферной безопасности». - 2015. - № 4 (62). - URL: http://agps-2006.narod.ru/ttb/2015-4/50-04-15.ttb.pdf (Дата 0бращения: 20.03.2020).

4. Кучер Н.Ю. Развитие коммуникативной мобильности у студентов музыкального колледжа в процессе музыковедческой подготовки: автореф. дисс. ... канд. пед. наук / Екатеринбург, Уральский государственный педагогический университет. 2017. 23 с.

5. Николаева Ж.В. Основы теории коммуникации: учеб.- метод. пособие для студентов по специальности 350400 «Связи с общественностью». Улан-Удэ: ВСГТУ, 2004. 274 C.

6. Каплина С.Е. Концептуальные и технологические основы формирования профессиональной мобильности будущих инженеров в процессе изучения гуманитарных дисциплин: дис .... д-ра пед. наук / Чебоксары, Чувашский гос. пед. ун-т. 2008. 568 с.

7. Психология музыкальной деятельности: Теория и практика: учеб. пособие для студ. муз. фак. высш. пед. учеб. заведений / ред. Г.М. Цыпин. М.: Издательский центр Академия, 2003. 368 с.

8. Бочкарев Л.Л. Психология музыкальной деятельности. М.: Классика-XXI, 2008. 352 с.

9. Бутенко Н.В. Художественная и эстетическая потребности как доминанта эмоциональных реакций в художественно-эстетическом развитии ребенка / Челябинск, Вестник Челябинского Государственного педагогического университета. 2014. №5. С. 26-37.

10. Кучер Н.Ю. Развитие коммуникативной мобильности у студентов музыкального колледжа в процессе музыковедческой подготовки: дисс. ... канд. пед. наук. Екатеринбург: Уральский государственный педагогический университет, 2017. 245 с.

11. Якупов А.Н. Теоретические проблемы музыкальной коммуникации: исследование. М.: Московская консерватория, Магнитог. муз-пед. ин-т, 1994. 292 с.

12. Основы музыкальной журналистики: учеб. пособие / под ред. Л.А. Птушко. Н.Новгород: Изд-во Нижегородской консерватории, 2014.80 с.

(с) Кучер Наталья Юрьевна (nataljakucher@yandex.ru).

Журнал «Современная наука: актуальные проблемы теории и практики» 